\title{
Waste Reduction by Improved Quality Control And Hadzad Analysis And Critical Control Point (HACCP) Implementation: A Case Study From Edfina Company For Presrved Foods, Alexandria, Sciendo Egypt
}

\section{El-Sayed El-Tanboly,'Mahmoud El-Hofi, Nabil Abd-Rabou, Youssef Bahr Youssef, Osama Ibrahim and Adel Kholif}

Food Technology and Nutrition Division, National Research Centre, Egypt.

*Corresponding Author's E-mail: tanboly1951@yahoo.com

Doi: $10.2478 / m j h r-2021-0006$

\section{Abstract:}

Under the Under the project Support for Environmental Assessment and Management (SEAM), This project is being implemented by Reduction of Milk Losses at Miser Company for Dairy and Food, Mansoura, Egypt. It was implemented under the National Industrial Pollution Prevention Programmers (NIPPP). NIPPP focuses on the introduction and promotion of low-cost improvement measures, which can be easily and quickly implemented by factories. It also emphasizes the importance of economic benefits of any such intervention, particularly those with short pay-back periods. A summary of how these improvements were identified and the underlying problems solved, follows. Waste minimization through improved quality control procedures was implemented at Edfina Company for Preserved Foods, Alexandria, Egypt. A number of interventions costing LE 65,200 (Egyptian Pound) have yielded annual savings of LE 382,622. Quality control training and the implementation of Hazard Analysis and Critical Control Point (HACCP) system will lead to improved product quality and further savings. Although it is difficult to quantify at this stage further savings of LE 550,000 could be expected in the short term.

Keywords: HACCP system, Jam fruits, Fruit Juices, Canned Beans - green beans, Tomato paste, frozen foods, honey

\subsection{Introduction}

Edfina is a public sector company and its factory at Montazah, Alexandria is one of the largest producer of preserved foods in Egypt. Built in 1958 on $56,000 \mathrm{~m} 2$ theplans, to its current level of 600 employees. Production is seasonal and is around 12,100 tons per year comprising: 4,600 tons of fruit juice and syrup; 3,900 tons of jam; 1,700 tons of canned beans and vegetables; 1,050 tons of frozen foods; 500 tons of tomato paste; and 350 tons of honey and other products (Figure 1).

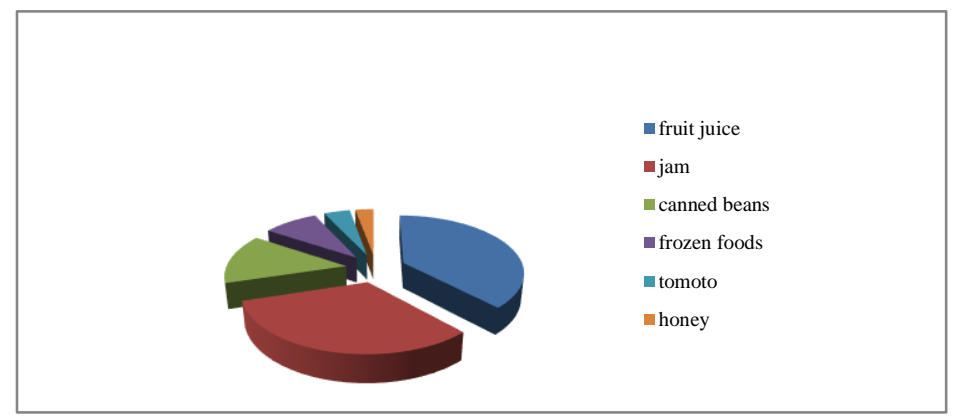

Figure 1: Edfina company for preserved foods products (ton/year).

\subsection{Process Description}

Processing at Edfina Company for Preserved Foods the 5 main products can be summarized as follows [1, 2].

\subsection{Fruit Juices}

Fresh fruits are received, sorted, washed and squeezed. Pulp is heated, screened and mixed with ingredients. The mixture is heated, screened, homogenized, either bottled or canned then pasteurized [3]. Product is incubated before final packaging and storage (Figure 2). Here are Nutrition Facts and Nutrition Facts 15 health benefits of orange juice [4, 5] that we can make use of in our daily life (Tables 1 and 2).

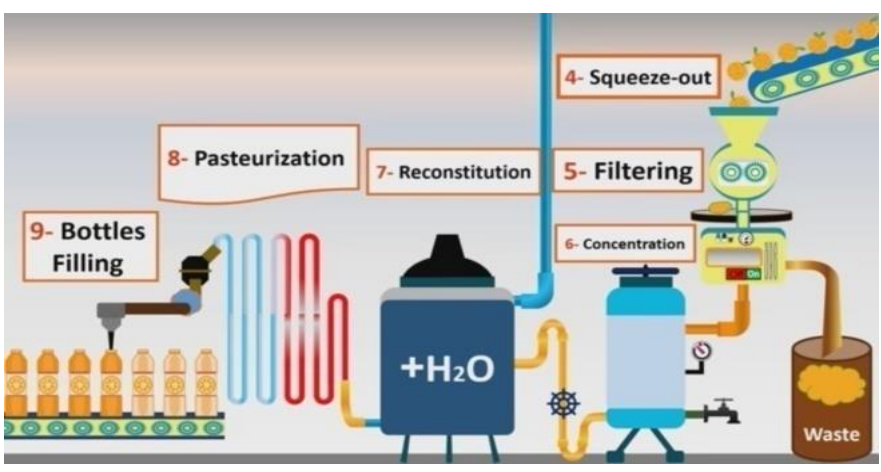

Figure 2: Fruit Juices Process description 
Table 1: Health benefits of orange juice

Health benefits of orange juice

Fortifies Our Immune System , Improves Digestive Health

Lowers the Risk of Cancer, Protects the Cardiovascular System

Prevents Kidney Diseases, Assists in Weight

Cleanses the Skin , Reduces Wrinkles

Improves Eyesight, It Has Incredible Healing Properties

Prevent Hair Loss, Makes Your Hair Beautiful

Lower Cholesterol Levels, It's A Natural Anti-Inflammatory

Provides Nutrients During Pregnancy

Table 2: Orange Juice Nutrition Facts

Orange Juice Nutrition Facts

Nutritional value per $248 \mathrm{~g}$ (1 cup)

\begin{tabular}{ll}
\hline Calories & $112 \mathrm{kcal}$ \\
Carbohydrate & $25.79 \mathrm{~g}$ \\
Sugar & $20.83 \mathrm{~g}$ \\
Dietary fiber & $0.50 \mathrm{~g}$ \\
Fat & $0.50 \mathrm{~g}$ \\
Saturated fat & 0.06 \\
Monounsaturated fat & 0.089 \\
Polyunsaturated fat & 0.099 \\
Protein & 1.74
\end{tabular}

\begin{tabular}{|c|c|c|}
\hline Vitamins & Quantity & \%DV* \\
\hline $\begin{array}{l}\text { Vitamin } \quad \text { A } \\
\text { equiv. } \\
\text { Vitamin A }\end{array}$ & $\begin{array}{l}25 \mu \mathrm{g} \\
496 \mathrm{IU}\end{array}$ & $3 \%$ \\
\hline Thiamine (B1) & $0.223 \mathrm{mg}$ & $19 \%$ \\
\hline Riboflavin (B2) & $0.074 \mathrm{mg}$ & $6 \%$ \\
\hline Niacin (B3) & $0.992 \mathrm{mg}$ & $7 \%$ \\
\hline Vitamin (B12) & $0.00 \mu \mathrm{g}$ & $0 \%$ \\
\hline Vitamin (B6) & $0.099 \mathrm{mg}$ & $8 \%$ \\
\hline Folate (B9) & $74 \mu \mathrm{g}$ & $19 \%$ \\
\hline Vitamin C & $124.0 \mathrm{mg}$ & $149 \%$ \\
\hline Vitamin $\mathrm{K}$ & $0.2 \mu \mathrm{g}$ & $0 \%$ \\
\hline Minerals & Quantity\% & $\mathrm{DV}^{*}$ \\
\hline Calcium & $27 \mathrm{mg}$ & $3 \%$ \\
\hline Iron & $0.50 \mathrm{mg}$ & $4 \%$ \\
\hline Magnesium & $27 \mathrm{mg}$ & $8 \%$ \\
\hline Sodium & $2 \mathrm{mg}$ & $0 \%$ \\
\hline Phosphorus & $42 \mathrm{mg}$ & $6 \%$ \\
\hline Potassium & $296 \mathrm{mg}$ & $11 \%$ \\
\hline Zinc & $0.12 \mathrm{mg}$ & $1 \%$ \\
\hline \multicolumn{2}{|l|}{ Other constituents } & Quantity \\
\hline \multicolumn{3}{|c|}{$\begin{array}{lc}\text { Water } & 218.98 \\
\text { * Percent Daily Values are based on a } 2000 \text { calorie diet. }\end{array}$} \\
\hline
\end{tabular}

\subsection{Jam Fresh Fruits}

Fruits are sorted, washed, peeled then cut. The fruit is then mixed with sugar, steam cooked and concentrated under vacuum. Concentrate is packed in tin cans, or jam pots, sterilized and Stored [6-8]. Table 3 Illustrated Nutrition Facts Jam fresh fruits.

\subsection{Frozen Vegetables Fresh}

Vegetables fresh are received, weighed, sorted, trimmed, peeled and cut manually. Peeled vegetables are sorted, blanched, frozen, sieved, and packed in pouches. Frozen vegetables are vegetables that have had their temperature reduced and maintained to below their freezing point for the purpose of storage and transportation until they are ready to be eaten (Table 4). They may be commercially packaged or frozen at home. A wide range of frozen vegetables are sold in supermarkets $[9,10]$. 
Table 3: Jam fresh fruits Nutrition Facts

Jam fresh fruits Nutrition Facts

12 Serving per container Serving size $19 \mathrm{~g}$

Calories 30

$\%$ Daily Value*

Total Fat $0 \mathrm{~g}$

Saturated fat $0 \mathrm{~g}$

$0 \%$.

Polyunsaturated fat $0 \mathrm{~g}$

$0 \%$

Monounsaturated fat $0 \mathrm{~g}$

Cholesterol $0 \mathrm{mg} \quad 0 \%$

Sodium $0 \mathrm{mg} \quad 0 \%$

Total Carbohydrate $8 \mathrm{~g} \quad 3 \%$

Dietary fiber $0 \mathrm{~g} \quad 0 \%$

Total sugar $6 \mathrm{~g}$

Includes $5 \mathrm{~g}$ sugar added sugars $\quad 10 \%$

Protein $0 \mathrm{~g} \quad 0 \%$

Vitamin D $0 \mathrm{mg} \quad 0 \%$

Calcium $0 \mathrm{mg} \quad 0 \%$

Iron $0 \mathrm{mg} \quad 0 \%$

Potassium $94 \mathrm{mg} \quad 2 \%$

* Percent Daily Values are based on a 2000 calorie diet.

Source: Nutrient data for this listing was provided by USDA

Table 4: Frozen vegetables Nutrition Facts

Frozen vegetables Nutrition Facts

Amount Per $100 \mathrm{~g}$

Calories 60

$\%$ Daily Value

Total Fat $0.2 \mathrm{~g}$

Saturated fat $0 \mathrm{~g}$

$0 \%$

Polyunsaturated fat $0.1 \mathrm{~g}$

$0 \%$

Monounsaturated fat $0 \mathrm{~g}$

Cholesterol $0 \mathrm{mg} \quad 0 \%$

Sodium $271 \mathrm{mg} \quad 11 \%$

Potassium $169 \mathrm{mg} \quad$ 4\%

Total Carbohydrate $13 \mathrm{~g} \quad 4 \%$

Dietary fiber $4.4 \mathrm{~g} \quad 17 \%$

Sugar $3.1 \mathrm{~g}$

Protein $2.9 \mathrm{~g} \quad 5 \%$

Vitamin A $235 \%$

Calcium $\quad 6 \%$

Vitamin D $\quad 0 \%$

Cobalamin $\quad 0 \%$

Vitamin C $\quad 14 \%$

Iron $\quad 12 \%$

Vitamin B-6 10\%

Magnesium $\quad 15 \%$

* Percent Daily Values are based on a 2000 calorie diet.

Source: Nutrient data for this listing was provided by USDA

\subsection{Canned Green Beans}

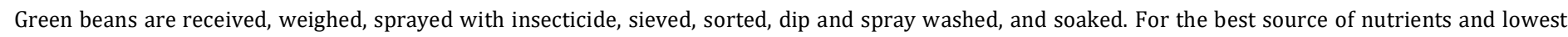
sodium, choose fresh or frozen greens beans for cooking. Green beans also contain folate, thiamin, riboflavin, iron, magnesium, and potassium.

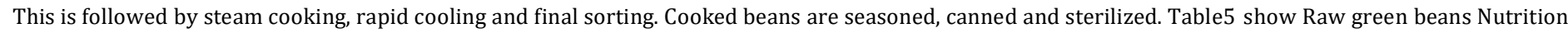

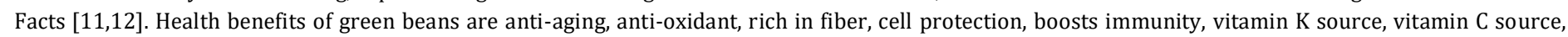
good folate source, cardiovascular health and manganese source [13].

\subsection{Tomato Paste}

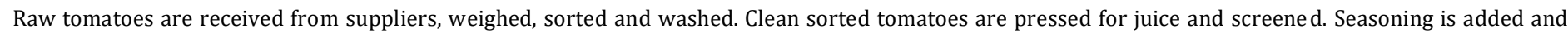

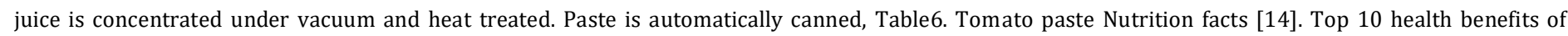

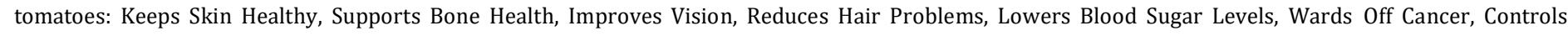
Weight, Promotes Sound Sleep, Lowers Blood Pressure, Reduces Chronic Pain. 


\subsection{Process and Service Units}

There are two canning facilities, a freezing unit, two can making plants, and a varnishing and printing facility on site. Service units include a water treatment facility, boiler station, quality control laboratories, freeze-storage and refrigerators in addition to cooling towers, garages and maintenance workshops $[10,15]$.

Table 5: Green beans Nutrition Facts

\begin{tabular}{|c|c|}
\hline Green beans Nutrition Fa & \\
\hline Amount Per $100 \mathrm{~g}$ & \\
\hline Calories 31 & \\
\hline \% Daily Value & \\
\hline Total Fat $0.1 \mathrm{~g}$ & $0 \%$ \\
\hline Saturated fat $0 \mathrm{~g}$ & $0 \%$ \\
\hline Polyunsaturated fat $0.1 \mathrm{~g}$ & \\
\hline Monounsaturated fat $0 \mathrm{~g}$ & \\
\hline Cholesterol $0 \mathrm{mg}$ & $0 \%$ \\
\hline Sodium $6 \mathrm{mg}$ & $0 \%$ \\
\hline Potassium 209mg & $5 \%$ \\
\hline Total Carbohydrate $7 \mathrm{~g}$ & $2 \%$ \\
\hline Dietary fiber $3.4 \mathrm{~g}$ & $13 \%$ \\
\hline Protein $1.8 \mathrm{~g}$ & $3 \%$ \\
\hline Vitamin A & $2 \%$ \\
\hline Calcium & $3 \%$ \\
\hline Vitamin D & $0 \%$ \\
\hline Cobalamin & $0 \%$ \\
\hline Vitamin C & $27 \%$ \\
\hline Iron & $5 \%$ \\
\hline Vitamin B-6 & $5 \%$ \\
\hline Magnesium & $6 \%$ \\
\hline
\end{tabular}

Source: Nutrient data for this listing was provided by USDA

Table 6: Raw Red Tomatoes Nutrition Facts

\begin{tabular}{|c|c|c|}
\hline \multicolumn{3}{|c|}{ Raw Red Tomatoes Nutrition Facts } \\
\hline \multicolumn{3}{|l|}{ Amount Per $100 \mathrm{~g}$} \\
\hline \multicolumn{3}{|l|}{ Calories $18 \mathrm{kcal}$} \\
\hline \multicolumn{3}{|l|}{ \% Daily Value } \\
\hline Fat & $0.2 \mathrm{~g}$ & \\
\hline Carbohydrate & $3.9 \mathrm{~g}$ & \\
\hline Dietary fiber & $1.2 \mathrm{~g}$ & \\
\hline Protein & $0.9 \mathrm{~g}$ & \\
\hline Vitamins & Quantity & $\% \mathrm{DV}^{*}$ \\
\hline Vitamin A equiv. & $42 \mu \mathrm{g}$ & $5 \%$ \\
\hline Thiamine (B1) & $449 \mu \mathrm{g}$ & $4 \%$ \\
\hline beta-Carotene & $123 \mu \mathrm{g}$ & \\
\hline lutein zeaxanthin & $123 \mu \mathrm{g}$ & \\
\hline Thiamine (B1) & $0.037 \mathrm{mg}$ & $3 \%$ \\
\hline Niacin (B3) & $0.594 \mathrm{mg}$ & $4 \%$ \\
\hline Vitamin B6 & $0.08 \mathrm{mg}$ & $6 \%$ \\
\hline Vitamin C & $14 \mathrm{mg}$ & $17 \%$ \\
\hline Vitamin E & $0.54 \mathrm{mg}$ & $4 \%$ \\
\hline Minerals & Quantity\% & $\mathrm{DV}^{*}$ \\
\hline Magnesium & $11 \mathrm{mg}$ & $3 \%$ \\
\hline Manganese & $0.114 \mathrm{mg}$ & $5 \%$ \\
\hline Phosphorus & $24 \mathrm{mg}$ & $3 \%$ \\
\hline Potassium & $237 \mathrm{mg}$ & $5 \%$ \\
\hline Other constituents & Quantity & \\
\hline Water & $94.5 \mathrm{~g}$ & \\
\hline Lycopene & $2573 \mu \mathrm{g}$ & \\
\hline
\end{tabular}

Source: Nutrient data for this listing was provided by USDA

\subsection{Energy and Water Consumption}

Annual consumption is typically electricity 5.95 million $\mathrm{kWh}$, fuel 2,419 tons and water700,000 m³. 


\subsection{Wastewater}

Around $520,000 \mathrm{~m}^{3} /$ year of effluent are discharged untreated into the public sewerage system. Table 7 show the analysis of final effluent. The factory is in the process of installing a wastewater treatment plant.

Table 7: Analysis of Final Effluent

\begin{tabular}{|ll|}
\hline Analysis of Final Effluent & \\
\hline Characteristics & Effluent quality \\
\hline Volume (m3/year) & 520,000 \\
BOD & 845 \\
COD & 1,445 \\
TSS & 2,225 \\
TDS & 1,275 \\
Oil \& Grease & 95 \\
\hline
\end{tabular}

BOD (ppm): Biochemical Oxygen Demand (Part per million);

COD (ppm) Chemical Oxygen Demand (Part per million), TSS (ppm)

Total Suspended solids (Part per million), TDS (ppm)

Total Dissolved soilds (Part per million)

\subsection{Cleaner Production Opportunities}

Cleaner production opportunities were initially identified by means of an industrial audit of the factory. An assessment was made of the different factory processes which highlighted high product losses and recalls at around 400 tons per annum. Table 8 show that Juice losses accounted for 204 tons ( $4.5 \%$ ); jam losses, 58 tons (15\%); tomato paste losses, 57 tons (11.5\%); frozen vegetables losses, 45 tons (4.5\%); and cooked bean losses, 23 tons (1.5\%). Issues that need addressing included: Quality control capabilities needed strengthening through additional employee training programmers, Product reject rates were high and could be reduced by better on-line production controls, Considerable amounts of jam pots were wasted due to faulty packaging, Manual packaging and poor handling of the vegetable paste resulted in un necessary losses [16], For frozen food production, vegetables are washed and cooled manually, Product rejects arise due to improper handling and Post blanching contamination, Insects were posing a problem to product quality particularly in jam production, Considerable amounts of packaging waste were generated particularly tin and reject cans (1,500 ton/year) and glass bottles (22 ton/year), Large amounts of steam and water were being wasted due to condensate losses, leaking valves, insufficient thermal insulation and excessive use of water and Pollution loads in discharge effluents were above permissible limits.

Table 8: Losses and Recalls (ton/year)

\begin{tabular}{|lll|}
\hline \multicolumn{2}{|l|}{ Losses and Recalls (ton/year) } & \\
\hline Preserved foods & $\begin{array}{l}\text { Losses and } \\
\text { (ton/year) }\end{array}$ & $\begin{array}{l}\text { \% Losses and } \\
\text { recalls }\end{array}$ \\
\hline Juice & 204 & 4.5 \\
Jam & 58 & 15 \\
Tomato paste & 57 & 11.5 \\
Frozen vegetables & 45 & 4.5 \\
Cooked bean & 23 & 1.5 \\
\hline
\end{tabular}

\subsection{Cleaner Production Application}

To address the above issues a series of improvement measures were identified and implemented. Priority was given to improvements that could entail significant savings at least cost.

\subsection{Involving the Employees}

An in-house team was established to identify opportunities for improvements that will minimize wastage in the factory's different production lines. The team was headed by the quality control manager, and included members from other key departments. The team enhanced the communication between all levels of management and workers and facilitated co-operation between the different departments.

\subsection{Quality Control Training and Awareness Raising}

A training needs assessment was undertaken with management, process engineers, production supervisors and line workers in order to tailor an appropriate employee training and awareness programmers. Training over 8 weeks was provided for 23 employees, mainly from the production and quality control departments, in the following areas [17,18] :Improved quality control for food industries, Good manufacturing practices in food processing, Hazard Analysis and Critical Control Point (HACCP) Systems, Cleaner Production principles and waste reduction techniques, On-line quality control monitoring and environmental measurements and Computer applications to improve monitoring, data analysis and reporting. Training manuals were disseminated and on the job training was an integral part of the programmers.

\subsection{Monitoring to Improve Process Control}

To reduce product losses, the factory's laboratory facilities were upgraded with partitioning, new benches and air conditioning. Additional equipment purchased to improve on-line monitoring included: Portable refract meters, $\mathrm{pH}$ meters, thermometers and color meters that provide quick and reliable online analysis of product quality, Turbidity meters to test process water quality, Computer, printer and software to improve monitoring of data and reporting of results. Consideration is also being given to obtaining: Equipment for testing coating thickness, can seams and vacuum seals, to reduce losses caused by canning defects and Environmental test kit and BOD. 


\subsection{Cleaner Production Interventions}

\subsubsection{Improve Packaging of Fruit Jam}

Packaging of jam in single-use foil pots was resulting in around $15 \%$ losses due to poor cutting and seal defects. During seasonal production as many as 12,000 pots ( 0.36 ton) were lost daily giving rise to annual losses of 43.2 tons. Improving the design of the trimming machine has overcome the problem and led to higher quality packaging. Operational costs are marginally lower. The new machine reduced downtime by $80 \%$ thereby increasing production capacity by $6 \%$ or 36 tons per year. Net marginal value of the increased capacity is LE16,200.

\subsubsection{Improve Packaging of Vegetable Pastes}

The blanched and chopped vegetable leaves "Molokhia" are packed manually resulting in handling and packaging losses of 17.5 tons per year. A semiautomatic packaging system made of a dispensing assemblage and a sealing device has been introduced to eliminate these losses. As a result, packaging time has been reduced by $50 \%$ thereby saving labor costs and increasing productivity.

\subsubsection{Modification to Vegetable Processing}

The production of frozen vegetables involved a lot of manual handling resulting in product losses and increasing the risk of contamination. To minimize manual handling during cooling of the vegetables after blanching a special sprinkler and screening system was installed. This measure has reduced product rejects by 10 tons per year. In addition, cooling water requirements were reduced by $25 \%(10,920 \mathrm{~m} 3 /$ year$)$ and labor requirements reduced by $30 \%$.

\subsubsection{Improve Pest Control}

The current pest control program was upgraded by installing window screens and insect cutters to control flying insects. Frequent inspection and pest surveys were also initiated. These improvements were required to bring the factory into line with international hygiene specifications and have eliminated 29.3 tons per year in product losses. 15\% losses in jam packaging were eliminated by improving the trimming mechanism for foil pots.

\subsection{Hazard Analysis and Critical Control Points (HACCP)}

A summary of the 12 HACCP implementation steps suggested by the [19]. Figure 2 Integrating HACCP with ISO9000 under one management system [18, 20].

Table 9: HACCP implementation steps

HACCP implementation steps

12. Establish documentation and records

11. Establish procedures for verification

10. Establish the corrective action

9. Establish a monitor control of CCP.

8. Establish critical limit(s) of CCP .

7. Determine the Critical Control Points (CCPs).

6. Conduct a hazard analysis.

5. Verify flow diagram

4. Construct flow diagram

3.Identify Intended Use

2. Describe the Product

1. Assemble HACCP

\subsection{Benefits and Achievements}

The main benefits of this project have been to reduce raw material wastage and product rejects through better quality control. Employee training, improved process monitoring and the preventative approach of HACCP have led to greater efficiencies and operational controls yielding benefits that are better quantified over time. The application of HACCP will be essential in maintaining and assured products from the United States and European buyers are already evident for the following: Frozen vegetables for which Edfina have exported 2,000 tons to Europe and the United States, valued at LE7.6 million and Fruit drinks for which Edfina presently exports 25 tons per year valued at LE73,000. HACCP that was implemented for bottled fruit drink production is being replicated by the factory in other production lines. Environmental improvements have included a reduction in water consumption, pollution loads and volume of effluent discharges.

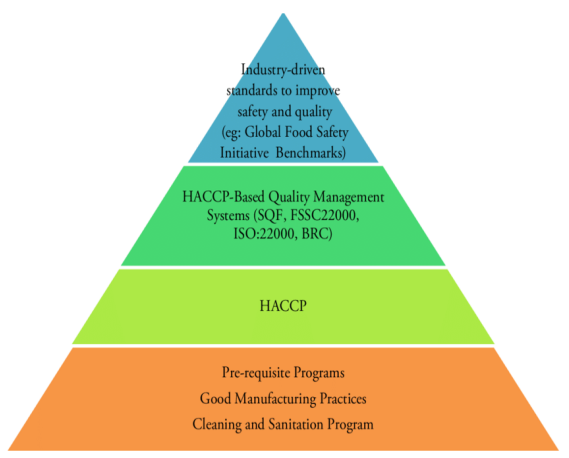

Figure 2: Integrating HACCP with ISO9000 


\subsection{Economics}

A summary of the cost benefits that have been quantified for the four interventions is given below Table 10. In addition to the above costs LE33,230 was spent on on-line monitoring equipment and a further LE40,000 was spent on quality control training and HACCP implementation. Although the direct benefits of improved quality control practices are difficult to quantify it is expected that in the short term at least a further $2 \%$ of wasted raw materials and products will be recovered yielding savings in excess of LE550,000.

Table 10: Intervention of packaging processing

\begin{tabular}{|c|c|c|c|}
\hline \multicolumn{4}{|c|}{ Intervention of packaging processing } \\
\hline Intervention & Costs LE* & $\begin{array}{l}\text { Annual } \\
\text { Savings }\end{array}$ & $\begin{array}{l}\text { Payback } \\
\text { Months }\end{array}$ \\
\hline $\begin{array}{l}\text { Improve } \\
\text { packaging of } \\
\text { fruit jam }\end{array}$ & 18,000 & 206,256 & 1 \\
\hline $\begin{array}{l}\text { Improve } \\
\text { packaging of } \\
\text { vegetable } \\
\text { paste }\end{array}$ & 13,950 & 57,750 & $<3$ \\
\hline $\begin{array}{l}\text { Modifications to } \\
\text { vegetable } \\
\text { processing }\end{array}$ & 10,750 & 49,720 & $<3$ \\
\hline $\begin{array}{l}\text { Improve pest } \\
\text { control }\end{array}$ & 22,500 & 68,896 & $<4$ \\
\hline Total & 65,200 & 382,622 & 2 \\
\hline
\end{tabular}

LE* Egyptian Pound

\subsection{Conclusion}

It has carried out focuses on the introduction and promotion of low-cost improvement measures, which can be easily and quickly implemented by factories. It also emphasises the importance of economic benefits of any such intervention, particularly those with short pay-back periods. Benefits of Pollution Prevention It can reduce: production costs; losses of valuable raw materials; on site treatment costs; energy and water costs; the volume of solid and liquid wastes generated; the risk of spills and accidents. and improve: overall operating efficiency; generation of income through reuse and recycling of wastes; this approach can be easily replicated in sister factories to achieve similar savings; safety of employees; legislative compliance and company image.

\subsection{Acknowledgement}

Thanks to the Food Technology and Nutrition Division, National Research Centre, Egypt for all experimental support.

\subsection{References}

[1] Y.H. Hui, "Handbook of Fruits and Fruits Processing, Blackwell Publishing, Oxford, Nutrient Analysis of Fruits and Vegetables: Analytical Report, Pp. 189$204,2006$.

[2] FDA/DHHS. "Hazard Analysis and Critical Control Point (HACCP); Procedures for the Safe and Sanitary Processing and Importing of Juice," Proposed Rule, 21 CFR Part 120, 63 FR20450-20486, April 24, 1998.

[3] D. Benton, and H.A. Young, "Role of fruit juice in achieving the 5-a-day recommendation for fruit and vegetable intake." Nutrition Reviews, Vol. 77, No. 11, Pp. 829-843, 2019.

[4] R.H. Schmidt, C.A. Sims, M.E. Parish, S. Pao, and M. A. Ismail. 1997. A model HACCP Plan for Small-Scale, Fresh Squeezed (Not Pasteurized) Citrus Juice Operations. Publication CIR 1179, Food Science and Nutrition Department, Florida Cooperative Extension Service, Institute of Food and Agricultural Sciences, University of Florida, 1997.

[5] Nutrition Facts and Analysis for Orange juice, raw. Nutritiondata.self.com. Retrieved 11 November 2012.

[6] M.E. Igual, M.M. García, N. Camacho, and M. Navarrete. "Jam processing and storage effects on $\beta$-carotene and flavonoids content in grapefruit", J. Funct. Foods, Vol. 5, Pp. 736-744, 2013.

[7] M.N. Naeem, M.K. Fairulniz, A. Norhayati, A.H. Zaiton, W.Z. Norliza, and W. Syuriaht, "The nutritional composition of fruit jams in the Malaysian market", Journal of the Saudi Society of Agricultural Sciences, Vol. 1, Pp. 89-96, 2017.

[8] L. McCarthy, “Jam On: The Craft of Canning Fruit”, Penguin Publishing Group, Pp. 141, 2012.

[9] P.E. Nelson, and D.K. Tressler, “Fruit and Vegetable Juice Processing Technology”, Westport, Connecticut: AVI Publishing Co, 1980.

[10] A.W. Ryan, “A Brief History of Fruit and Vegetable Juice Regulation in the United States”. Works.bepress.com. Retrieved. 2015.

[11] L.S. Joanne and B. Lloyd, “Health Benefits of Fruits and Vegetables”, J. Adv NutrJul., Vol. 3, No. 4, Pp. 506-516, 2012. 
[12] P.R. Wonning, “Gardeners' Guide to Growing Green Beans in the Vegetable Garden”, The Green Bean Book - Growing Bush, Pole Beans For Beginning Gardeners, 2018.

[13] S. Sengupta, “Go Green! 7 Incredible Health Benefits of Green Beans”, Ndef Food, 2018.

[14] V.R. Boswell, "Improvement and Genetics of Tomatoes, Peppers, and Eggplant”, Yearbook of Agriculture, U.S. Department of Agriculture, 1937, Pp. 179, 2018.

[5] J.L. Slavin, and B. Lloyd, "Health Benefits of Fruits and Vegetables1", Advances in Nutrition, Vol. 3, No. 4, Pp. 506-516, 2012.

[16] W.L. Bennet, and L.L. Steed, “An integrated approach to food safety”, Quality Progress, Milwaukee, United States, Milwaukee, Vol. 32, No. 2, Pp. 37-42, 1999.

[17] Canadian Food Inspection Agency (CFIA). Food Safety Enhancement Program, 2001.

[18] Codex Alimentarius Commission (CAC). "Guidelines for application of Hazard Analysis and Critical Control Point (HACCP) system”, Food Hygiene (Basic Texts) Fourth edition, WHO/FAO, Rome, 2009.

[19] Food and Drug Administration. (FDA), "Guidance for Industry: Juice HACCP Hazards and Controls Guidance, First Edition". Archived from the original, 2007.

[20] International Standard Organization (ISO). "Guidelines for application of ISO9001 and ISO9002 in the food and drink industry", ISO/DIS 1516. Switzerland, 1998. 